\title{
FAKTOR-FAKTOR YANG MEMPENGARUHI PERMINTAAN TELUR ITIK DI KABUPATEN JEMBER
}

\author{
Factors That Influence Demand for Duck Egg In Jember Regency \\ Deni Nur Hidayatullah', Merry Muspita Dyah Utami' ${ }^{2}$, dan Anang Febri Prasetyo ${ }^{2}$ \\ ${ }_{1}^{1}$ Program Studi Manajemen Bisnis Unggas, Jurusan Peternakan, Politeknik Negeri Jember \\ 2Jurusan Peternakan, Politeknik Negeri Jember \\ Email: denynur70@gmail.com
}

\begin{abstract}
ABSTRAK
Kabupaten Jember merupakan daerah yang memiliki produksi telur itik yang cukup tinggi. Hasil produksi telur itik di Kabupaten Jember sebagian besar terserap oleh permintaan dari konsumen rumah tangga, pedagang telur, dan produsen telur asin. Permintaan masyarakat diperkirakan akan meningkat terhadap telur itik. Faktor yang diperkirakan mempengaruhi permintaan telur itik di Kabupaten Jember diantaranya harga komoditi barang, harga barang lain, pendapatan, jumlah anggota keluarga, intensitas kebutuhan, dan selera. Tujuan dari penelitian ini adalah menganalisis pengaruh faktor-faktor tersebut terhadap permintaan telur itik di Kabupaten Jember, mengetahui faktor yang berpengaruh dominan, dan mengetahui elastisitas permintaan telur itik di Kabupaten Jember. Metode yang digunakan adalah metode penelitian survei dengan jumlah responden sebanyak 80 responden. Teknik pengumpulan data menggunakan kuisioner dan teknik analisis yang digunakan adalah analisis regresi linier berganda, Uji F, uji t, dan elastisitas permintaan. Hasil penelitian menunjukkan bahwa variabel harga telur itik, harga telur ayam ras, pendapatan keluarga, jumlah anggota keluarga, jumlah kebutuhan, dan dummy selera secara serempak berpengaruh signifikan terhadap permintaan telur itik di Kabupaten Jember. Harga telur itik paling dominan berpengaruh secara parsial terhadap permintaan telur itik. Permintaan telur itik bersifat inelastis, telur ayam ras merupakan barang subtitusi, dan telur itik merupakan kategori barang normal.
\end{abstract}

Kata kunci: Deskriptif, Elastisitas, Jember, Permintaan, Telur Itik

\begin{abstract}
Jember Regency is an area that has a fairly high production of duck eggs. The production of duck eggs in Jember Regency is largely absorbed by demand from household consumers, egg traders, and producers of salted eggs. Public demand is expected to increase with duck eggs. Factors expected to influence demand for duck eggs in Jember Regency are the price of goods, prices of other goods, income, number of family members, intensity of needs, and tastes. The purpose of this research was to analyze the influence of these factors on the demand for duck eggs in Jember Regency, determine the factors that have a dominant influence, and the elasticity of demand for duck eggs in Jember Regency. The method used was a survey research method with a total sample of 80 respondents. Data collection techniques using questionnaires and analysis techniques used were multiple linear regression analysis, $F$ test, $t$ test, and elastic of demand. The results indicated that variable price of duck eggs, price of broiler eggs, family income, number of families, number of needs, and taste dummy simultaneously significantly affect to the demand of duck egg in Jember Regency. The most dominant variable affecting the demand of duck eggs was the price of duck eggs. The Demand of duck eggs was inelastic, broiler eggs were substitute items, and duck eggs were normal items.
\end{abstract}

Keywords: Descriptive, Elasticity, Jember Regency, Demand, Duck Eggs 


\section{PENDAHULUAN}

Telur itik merupakan salah satu komoditi pangan yang memiliki cita rasa yang khas dan mengandung gizi yang tinggi, hal tersebut membuat telur itik banyak diminati oleh masyarakat. Telur itik juga banyak dimanfaatkan masyarakat sebagai olahan pangan, bahan dalam pembuatan kue, jajanan martabak, serta yang menjadi pembeda dengan telur lainnya adalah diawetkan menjadi telur asin.

Kabupaten Jember merupakan daerah yang memiliki total populasi itik petelur tahun 2018 sebanyak 190 ribu ekor dengan jumlah produksi telur 1,3 juta kg per tahun (Dinas Peternakan Jawa Timur, 2018). Berikut tabel mencantumkan data produksi telur di Kabupaten Jember.

Tabel 1. Produksi telur di Kabupaten Jember Tahun 2014-2018

\begin{tabular}{lccccc}
\hline \multirow{2}{*}{ Komoditi } & \multicolumn{5}{c}{ Tahun $(\mathrm{kg})$} \\
\cline { 2 - 6 } & 2014 & 2015 & 2016 & 2017 & 2018 \\
\hline Telur Ayam Ras & 6.438 .329 & 11.251 .121 & 11.419 .891 & 11.653 .040 & 11.773 .975 \\
Telur Ayam Buras & 936.614 & 974.075 & 988.685 & 1.005 .575 & 1.097 .465 \\
Telur Itik & 1.172 .681 & 1.196 .134 & 1.337 .184 & 1.350 .519 & 1.354 .504 \\
\hline
\end{tabular}

Sumber : Dinas Peternakan Jawa Timur (2018)

Data produksi telur itik pada tabel 1. menunjukkan peningkatan produksi dari tahun ke tahun. Peningkatan tersebut berkaitan dengan populasi penduduk Kabupaten Jember. Data jumlah populasi penduduk Kabupaten Jember tahun 2014 sebanyak 2.329.726 jiwa, meningkat menjadi 2.440.714 jiwa pada tahun 2018 (BPS Kabupaten Jember, 2019).

Mengingat bertambahnya populasi jumlah penduduk yang tinggi, apakah berkaitan dengan meningkatnya jumlah konsumsi dan permintaan telur itik, sehingga dibutuhkan peningkatan produksi telur lebih untuk mencukupi permintaan telur itik. Telur itik di peternak-peternak Kabupaten Jember sebagian besar diserap oleh permintaan daripada konsumen rumah tangga, pedagang telur, dan produsen telur asin. Melihat jumlah produksi telur itik meningkat setiap tahun, maka jumlah kebutuhan telur itik meningkat dipasaran.

Permintaan masyarakat terhadap telur itik diperkirakan akan meningkat untuk masa yang akan datang. Fenomena telur ayam ras yang seringkali mengalami kenaikan harga menyebabkan menurunnya jumlah permintaan oleh konsumen. Berbeda dengan telur itik, meskipun harganya lebih tinggi dari telur ayam ras namun jumlah permintaan dan harganya tetap stabil dipasaran. Faktor penyebab yang diperkirakan mempengaruhi permintaan telur itik di Kabupaten Jember diantaranya harga komoditi barang itu sendiri, harga barang lain, pendapatan, jumlah anggota keluarga, intensitas kebutuhan, dan selera. Sebagaimana hasil penelitian Fridayanti et al. (2018) yang menyatakan variabel yang mempengaruhi permintaan telur ayam di Kabupaten Magetan diantaranya adalah harga telur ayam ras, harga daging ayam, harga beras, jumlah penduduk dan pendapatan perkapita.

Ketersediaan telur itik sebagai pemenuhan kebutuhan pangan sangat perlu diperhatikan terutama menjaga keseimbangan kebutuhan konsumen akan telur itik, dengan demikian perlu adanya analisis mengenai faktor-faktor yang mempengaruhi permintaan telur itik di Kabupaten Jember. Penelitian ini bertujuan untuk mengkaji variabel harga telur itik, harga telur ayam ras, pendapatan keluarga, jumlah anggota keluarga, jumlah kebutuhan, dan selera terhadap permintaan telur itik di Kabupaten Jember. Selain itu, bertujuan untuk mengkaji variabel yang berpengaruh dominan terhadap permintaan telur itik dan besarnya elastisitas permintaan telur itik di Kabupaten Jember. 


\section{METODE}

Penelitian ini telah dilaksanakan pada tanggal 21 Februari sampai dengan 11 Maret 2020 di Kabupaten Jember. Metode yang digunakan adalah metode penelitian survei. Metode survei dilakukan untuk mengumpulkan informasi dari responden dengan menggunakan kuisioner sebagai alat pengumpulan data. Lokasi yang menjadi sampel diantaranya Kecamatan Arjasa, Kecamatan Kaliwates, Kecamatan Sumbersari, dan Kecamatan Pakusari. Pemilihan lokasi didasari oleh lokasi yang bukan menjadi sentra produksi telur itik dan diharapkan dapat mewakili wilayah di Kabupaten Jember.

Responden konsumen telur itik memiliki kriteria berusia 18 sampai 60 tahun, sudah berkeluarga, mengkonsumsi telur itik minimal satu kali dalam sebulan, dan berdomisili di wilayah Kabupaten Jember. Jumlah sampel yang menjadi responden adalah 80 orang, dilakukan dengan teknik pengambilan sampel menggunakan Purposive Sampling.

\section{Variabel Penelitian}

Variabel dalam penelitian ini dibedakan menjadi dua yaitu variabel terikat (dependent) yaitu permintaan telur itik (Y) dan variabel bebas (independent) meliputi, harga telur itik $\left(\mathrm{X}_{1}\right)$, harga telur ayam ras $\left(X_{2}\right)$, pendapatan keluarga $\left(X_{3}\right)$, jumlah anggota keluarga $\left(X_{4}\right)$, jumlah kebutuhan $\left(X_{5}\right)$, dan selera konsumen (D) yang dinyatakan dalam variabel dummy.

\section{Definisi Operasional}

Definisi operasional pada penelitian ini antara lain 1) Telur itik, dalam penelitian ini adalah telur itik segar dan telur yang telah diawetkan menjadi telur asin, berasal dari ternak unggas itik petelur. 2) Konsumen telur itik, dalam penelitian ini adalah seseorang yang berusia 18 sampai 60 tahun, sudah berkeluarga, mengkonsumsi telur itik minimal satu kali dalam sebulan, berdomisili di wilayah Kabupaten Jember. 3) Permintaan telur itik, dalam penelitian ini adalah jumlah telur itik yang ingin dibeli oleh konsumen telur itik dalam waktu sebulan yang dihitung dalam satuan butir. 4) Harga telur itik, dalam penelitian ini adalah nilai komoditi telur itik yang berlaku di pasar, dihitung dalam satuan rupiah/butir. 5) Harga telur ayam ras, dalam penelitian ini adalah nilai komoditi telur ayam ras yang berlaku di pasar, dihitung dalam satuan rupiah/butir. 7) Pendapatan keluarga, dalam penelitian ini adalah pendapatan total seluruh anggota keluarga dalam sebulan (dalam rupiah). 8) Jumlah anggota keluarga, dalam penelitian ini adalah banyaknya tanggungan anggota keluarga dari responden. 9) Jumlah kebutuhan, dalam penelitian ini adalah jumlah frekuensi pembelian telur itik dalam sebulan. 10) Selera, dalam penelitian ini adalah suka atau tidaknya konsumen terhadap telur itik, ditentukan dengan skor dummy yaitu skor 1 untuk tidak suka dan skor 2 untuk suka.

\section{Prosedur Pengumpulan Data}

Jenis data yang digunakan dalam penelitian ini adalah data primer dan data sekunder. Data primer diperoleh melalui pengisian kuisioner dengan wawancara langsung terhadap responden konsumen telur itik di Kabupaten Jember. Data sekunder digunakan untuk tujuan sebagai penunjang penelitian. Data sekunder diperoleh dari studi literatur serta dari instansi terkait yang berhubungan dengan penelitian ini.

\section{Metode Analisis Data}

Metode analisis data yang digunakan dalam penelitian ini menggunakan analisis regresi linier berganda, yaitu untuk mengetahui hubunga variabel antara variabel bebas diantaranya harga telur itik $\left(\mathrm{X}_{1}\right)$, harga telur ayam ras $\left(\mathrm{X}_{2}\right)$, pendapatan keluarga $\left(\mathrm{X}_{3}\right)$, jumlah keluarga $\left(\mathrm{X}_{4}\right)$, jumlah kebutuhan 
$\left(\mathrm{X}_{5}\right)$, dan dummy selera (D) dengan variabel terikat yaitu permintaan telur itik di Kabupaten Jember (Y). Persamaan matematis regresi linier berganda untuk permintaan telur itik sebagai berikut:

$$
Y=a+b_{1} X_{1}+b_{2} X_{2}+b_{3} X_{3}+b_{4} X_{4}+b_{5} X_{5}+b_{6} D_{6}+e
$$

Keterangan

Y : Permintaan telur itik (butir/bln)

a : Konstanta

$b_{i} \quad$ : Koefisien regresi variabel ke-i $(i=1,2, . .6)$

$\mathrm{X}_{1} \quad$ : Harga telur itik (Rp/butir)

$\mathrm{X}_{2} \quad$ : Harga telur ayam ras (Rp/butir)

$\mathrm{X}_{3} \quad$ : Pendapatan keluarga $(\mathrm{Rp} / \mathrm{bln})$

$\mathrm{X}_{4} \quad$ : Jumlah anggota keluarga (orang)

$\mathrm{X}_{5} \quad$ : Jumlah kebutuhan (frekuensi pembelian telur itik sebulan)

D : Dummy selera

e : error

Persamaan diatas selain menghasilkan nilai koefisien regresi juga menghasilkan nilai elastisitas permintaan dengan melihat nilai koefisien regresi masing-masing variabel penduganya. Persamaan matematis tersebut selanjutnya akan dlakukan uji asumsi klasik sebagai syarat dalam penerapan analisis regresi yang meliputi uji normalitas, uji multikolinearitas, dan uji heteroskedastisitas.

Data analisis statistik lain yang dibutuhan untuk mendukung keakuratan hasil penelitian diantaranya nilai koefisien determinasi, digunakan untuk mengetahui besar keragaman yang diterangkan oleh variabel independent terhadap variabel dependent. Uji $\mathrm{F}$ digunakan untuk mengetahui tingkat signifikan koefisien regresi variabel independent secara serempak terhadap variabel dependent dan uji t digunakan untuk mengetahui seberapa jauh pengaruh satu variabel independent secara individu terhadap variabel dependent.

\section{HASIL DAN PEMBAHASAN}

\section{Pengujian Asumsi Klasik}

Uji normalitas digunakan untuk mengetahui apakah model regresi linier terdistribusi secara normal atau tidak. Uji normalitas dapat dilakukan menggunakan statistik Kolgomorov-Smirnov. Kriteria yang digunakan dalam tes ini adalah data tersebut dikatakan berdistribusi normal apabila signifikansi $>0,05$. hasil uji normalitas menunjukkan nilai signifikansi $0,189>0,05$. Artinya data tersebut terdistribusi normal.

Uji multikolinearitas digunakan untuk mengetahui ada tidaknya korelasi yang tinggi antara variabel independent dalam suatu model regresi linier berganda. Penentuan keputusan untuk mengetahui ada tidaknya gejala multikolinearitas apabila nilai VIF $<10$ dan Tolerance $>0,1$ maka dinyatakan tidak terjadi multikolinearitas (Purnomo, 2016). Hasil uji menunjukkan nilai VIF variabel harga telur itik $\left(X_{1}\right)$ sebesar 1,107, harga telur ayam ras $\left(X_{2}\right)$ sebesar 1,336, pendapatan keluarga $\left(X_{3}\right)$ sebesar 1,541, jumlah keluarga $\left(X_{4}\right)$ sebesar 1,112, jumlah kebutuhan $\left(X_{5}\right)$ sebesar 1,619, dan dummy selera (D) sebesar 1,669 lebih kecil 10 dan Nilai Tolerance variabel harga telur itik $\left(\mathrm{X}_{1}\right)$ sebesar 0,904, harga telur ayam ras $\left(X_{2}\right)$ sebesar 0,749 , pendapatan keluarga $\left(X_{3}\right)$ sebesar 0,649 , jumlah keluarga $\left(\mathrm{X}_{4}\right)$ sebesar 0,899, jumlah kebutuhan $\left(\mathrm{X}_{5}\right)$ sebesar 0,618, dan dummy selera (D) sebear 0,599 lebih besar dari 0,10. Maka dapat disimpulkan bahwa tidak terjadi multikolinearitas antar variabel independent. 
Uji heteroskedastisitas dilakukan untuk mengetahui ada tidaknya kesalahan pengganggu dalam varian yang sama dari satu pengamatan (responden) dengan pengamatan lain dalam model regresi linier. Uji ini yang dapat dilakukan menggunakan metode korelasi Spearman's rho. Pengambilan keputusan apabila signifikansi lebih dari 0,05 maka dikatakan tidak terjadi masalah heteroskedastisitas (Purnomo, 2016). Hasil uji menunjukkan nilai signifikansi variabel harga telur itik $\left(X_{1}\right)$ sebesar 0,275 , harga telur ayam ras $\left(X_{2}\right)$ sebesar 0,789 , pendapatan keluarga $\left(X_{3}\right)$ sebesar 0,100 , jumlah keluarga $\left(\mathrm{X}_{4}\right)$ sebesar 0,539 , jumlah kebutuhan $\left(\mathrm{X}_{5}\right)$ sebesar 0,606 , dan dummy selera (D) sebesar 0,443 lebih besar dari 0,05. Artinya, tidak terjadi masalah heteroskedastisitas.

\section{Faktor-faktor yang Mempengaruhi Permintaan Telur Itik}

Dari hasil analisis, diketahui konstanta dan koefisien regresi yang diperoleh apabila dimasukkan pada persamaan umum regresi adalah sebagai berikut:

$$
Y=22,781-0,017 X_{1}+0,008 X_{2}+0,0000007458 X_{3}+0,339 X_{4}+1,956 X_{5}+5,837 D
$$

Tabel 2. Hasil Analisis Regresi Linier Berganda

\begin{tabular}{lccc}
\hline \multicolumn{1}{c}{ Variabel } & Koefisien & Standart Error & Sig \\
\hline (Constant) & 22,781 & 11,734 & 0,017 \\
Harga Telur Itik (X1) & $-0,017$ & 0,002 & 0,000 \\
Harga Telur Ayam Ras (X2) & 0,008 & 0,007 & 0,261 \\
Pendapatan Keluarga (X3) & $7,458 \mathrm{E}-7$ & 0,000 & 0,355 \\
Jumlah Anggota Keluarga (X4) & 0,399 & 0,680 & 0,559 \\
Jumlah Kebutuhan (X5) & 1,956 & 0,737 & 0,010 \\
Selera (D) & 5,837 & 1,686 & 0,001 \\
R $^{2}$ & 0,688 & & \\
F Hitung & 29,986 & & 0,000 \\
\hline
\end{tabular}

Sumber : Data Primer (2020)

\section{Koefisien Determinasi}

Berdasarkan tabel 2. nilai $R$ Square adalah sebesar 0,688 atau 68,8\%. Artinya, besarnya pengaruh variabel harga telur itik $\left(X_{1}\right)$, harga telur ayam ras $\left(X_{2}\right)$, pendapatan keluarga $\left(X_{3}\right)$, jumlah anggota keluarga $\left(\mathrm{X}_{4}\right)$, jumlah kebutuhan $\left(\mathrm{X}_{5}\right)$, dan dummy selera (D) terhadap permintaan telur itik (Y) di Kabupaten Jember sebesar 68,8\% dan sisanya 31,2\% dipengaruhi oleh faktor lain yang tidak diteliti dalam penelitian ini.

\section{Pengaruh Secara Serempak Variabel (X) Terhadap Variabel (Y)}

Berdasarkan Tabel 2. Hasil analisis uji F menunjukkan nilai signifikansi 0,05 lebih kecil dari taraf signifikansi $0,05(0,000<0,05)$, Artinya, bahwa variabel harga telur itik $\left(\mathrm{X}_{1}\right)$, harga telur ayam ras $\left(\mathrm{X}_{2}\right)$, pendapatan keluarga $\left(\mathrm{X}_{3}\right)$, jumlah anggota keluarga $\left(\mathrm{X}_{4}\right)$, jumlah kebutuhan $\left(\mathrm{X}_{5}\right)$, dan dummy selera (D) secara serempak berpengaruh signifikan terhadap permintaan telur itik (Y).

\section{Pengaruh Secara Parsial Variabel (X) Terhadap Variabel (Y)}

Berdasarkan hasil uji t pada tabel 2. menunjukkan bahwa nilai signifikansi variabel harga telur itik $\left(X_{1}\right)$ sebesar 0,000, jumlah kebutuhan $\left(X_{5}\right)$ sebesar 0,10, dan selera (D) sebesar 0,001 lebih kecil dari taraf sigmifikansi 0,05 . Artinya, variabel tersebut secara parsial berpengaruh signifikan 
terhadap permintaan telur itik di Kabupaten Jember. Sementara nilai signifikansi variabel harga telur ayam ras $\left(\mathrm{X}_{2}\right)$ sebesar 0,261 , pendapatan keluarga $\left(\mathrm{X}_{3}\right)$ sebesar 0,355 , dan jumlah anggota keluarga $\left(\mathrm{X}_{4}\right)$ sebesar 0,559 lebih besar dari signifikansi 0,05. Artinya, variabel tersebut secara parsial tidak berpengaruh signifikan terhadap permintaan telur itik di Kabupaten Jember. Variabel yang berpengaruh paling besar terhadap permintaan telur itik di Kabupaten Jember adalah harga telur itik dengan nilai t hitung sebesar 8,013; kemudian diikuti variabel dummy selera dengan nilai t hitung 3,462; variabel jumlah kebutuhan dengan t hitung sebesar 2,654.

Harga telur itik dipasaran Kabupaten Jember memiliki perbedaan harga disetiap tingkat penjual. Harga telur itik ditingkat peternak dijual dengan harga Rp. 1700 per butir, ditingkat tengkulak sebesar Rp. 2000 per butir, kemudian ditingkat penjual eceran seperti di pasar, warung, toko harga telur itik segar maupun telur asin berkisar antara Rp. 2500 sampai Rp. 3000 per butir. Sebagian besar konsumen telur itik menyatakan bahwa harga telur itik yang dijual dipasaran masih dapat dikategorikan dalam harga yang terjangkau. Harga menentukan seberapa besar jumlah barang yang akan diminta, sehingga harga merupakan salah satu faktor penentu banyak atau sedikitnya barang yang dibeli oleh konsumen (Bangun, 2017).

Variabel harga telur ayam ras $\left(\mathrm{X}_{2}\right)$ secara parsial tidak berpengaruh signifikan terhadap permintaan telur itik (Y). Hal tersebut terjadi karena harga telur ayam ras yang lebih murah dari telur itik yaitu sebesar Rp. 1500 per butir. Konsumen berpendapat bahwa dengan harga telur ayam ras yang lebih murah dari telur itik menjadikan telur ayam ras dapat menjadi pilihan alternatif lauk pauk untuk dikonsumsi selain telur itik. Hasil yang berbeda ditunjukkan pada penelitian Isman et al. (2014) yang menyatakan bahwa variabel harga telur itik berpengaruh secara parsial terhadap permintaan telur ayam ras di Provinsi Aceh.

Pendapatan konsumen merupakan salah satu faktor yang diduga berpengaruh terhadap jumlah permintaan telur itik di Kabupaten Jember. Hasil pengujian diperoleh variabel pendapatan keluarga $\left(\mathrm{X}_{3}\right)$ secara parsial tidak berpengaruh signifikan terhadap permintaan telur itik $(\mathrm{Y})$. Hal ini terjadi karena jumlah pendapatan keluarga dalam penelitian yang berkisar antara Rp. 1.500.0005.000.000 per bulan, dengan pendapatan keluarga demikian maka konsumen berasumsi mampu untuk membeli telur itik untuk dikonsumsi secara kontinyu. Dari hal tersebut pertimbangan pendapatan terhadap pembelian telur itik menjadi kurang berpengaruh secara besar.

Variabel jumlah anggota keluarga $\left(\mathrm{X}_{4}\right)$ tidak berpengaruh signifikan terhadap permintaan telur itik di Kabupaten Jember. Data responden menunjukkan dalam satu keluarga rata-rata memiliki jumlah anggota keluarga sebanyak 2-6 orang. Dalam satu keluarga, selera masing-masing orang berbeda terhadap telur itik. Tidak semua anggota keluarga suka mengkonsumsi telur itik sebagai lauk, dengan adanya perbedaan selera tersebut akan memunculkan pertimbangan disetiap keluarga dalam pembelian telur itik. Berbeda dengan hasil penelitian Murdani (2018) menunjukkan bahwa variabel jumlah tanggungan atau anggota keluarga berpengaruh signifikan terhadap permintaan telur ayam ras di Desa Tambon Kabupaten Aceh Utara.

Jumlah kebutuhan merupakan frekuensi pembelian oleh responden dalam pembelian telur itik selama sebulan. Hasil uji t menunjukkan variabel jumlah kebutuhan $\left(\mathrm{X}_{6}\right)$ secara parsial berpengaruh signifikan terhadap permintaan telur itik (Y). Responden dalam sebulan melakukan pembelian telur itik sebanyak 1 sampai 5 kali dalam sebulan. Dalam setiap pembelian responden membeli telur itik sebanyak 1 sampai 10 butir, kemudian sebagian besar responden menyatakan secara konsisten melakukan pembelian telur itik setiap bulannya. Jumlah kebutuhan menunjukkan pengaruh terhadap permintaan telur itik. Sejalan dengan hasil penelitian Fridayanti et al. (2018) yang menyatakan bahwa intensitas kebutuhan berpengaruh secara parsial terhadap jumlah permintaan telur ayam ras di Kabupaten Magetan. 
Variabel dummy selera merupakan variabel yang yang menggambarkan suka atau tidaknya konsumen terhadap telur itik. Hasil analisisi uji t menunjukkan bahwa variabel dummy selera (D) secara parsial berpengaruh signifikan terhadap permintaan telur itik (Y). Data responden menunjukkan 55 dari 80 responden menyatakan suka terhadap telur itik segar maupun telur itik asin. Responden yang menyatakan suka karena memiliki alasan diantaranya suka terhadap rasa yang khas dari telur itik, kandungan nutrisi yang ada didalam telur itik, haraga telur itik yang murah, dan kemudahan untuk membeli telur itik di lingkungan tempat tinggal. Dengan meningkatnya selera dari konsumen, tentu akan mendorong konsumen untuk membeli telur itik secara kontinyu sehingga permintaan telur itik akan bertambah. Sejalan dengan pendapat dari Hartono (2016) yang menyatakan penentu paling jelas terhadap permintaan adalah selera, tinggi rendahnya suatu permintaan ditentukan oleh selera atau kebiasaan dari pola hidup suatu masyarakat.

\section{Elastisitas Permintaan Telur Itik di Kabupaten Jember}

Berdasarkan tabel 3. nilai elastisitas harga telur itik sebesar -0,017. Nilai negatif menunjukkan bahwa variabel harga telur itik mempunyai hubungan terbalik dengan permintaan telur itik. Jika harga telur itik naik 1\% maka permintaan telur itik akan turun sebesar 0,017\%, begitu juga sebaliknya. Menurut Suardi (2019), angka elastisitas umumnya bernilai negatif karena sifat variabel harga dan jumlah barang yang diminta bersifat terbalik. Nilai koefisien elastisitas harga telur itik yang kurang dari 1 maka dikatakan permintaan bersifat inelastis, yang artinya besarnya persentase perubahan jumlah barang yang diminta lebih kecil dari persentase perubahan faktor yang mempengaruhinya.

Tabel 3. Nilai Elastisitas Permintaan Telur Itik di Kabupaten Jember

\begin{tabular}{lccc}
\hline \multirow{2}{*}{ Variabel } & \multicolumn{3}{c}{ Nilai Elastisitas } \\
\cline { 2 - 4 } & Harga & Silang & Pendapatan \\
\hline Harga Telur Itik (X1) & $-0,017$ & & \\
Harga Telur Ayam Ras (X2) & & 0,008 & \\
Pendapatan Keluarga (X3) & & & 0,000007458 \\
\hline
\end{tabular}

Sumber : Data Primer (2020)

Berdasarkan tabel 3. nilai elastisitas harga telur itik sebesar -0,017. Nilai negatif menunjukkan bahwa variabel harga telur itik mempunyai hubungan terbalik dengan permintaan telur itik. Jika harga telur itik naik 1\% maka permintaan telur itik akan turun sebesar 0,017\%, begitu juga sebaliknya. Menurut Suardi (2019), angka elastisitas umumnya bernilai negatif karena sifat variabel harga dan jumlah barang yang diminta bersifat terbalik. Nilai koefisien elastisitas harga telur itik yang kurang dari 1 maka dikatakan permintaan bersifat inelastis, yang artinya besarnya persentase perubahan jumlah barang yang diminta lebih kecil dari persentase perubahan faktor yang mempengaruhinya.

Nilai elastisitas silang dari harga telur ayam ras adalah 0,008. Artinya, jika harga telur ayam ras naik sebesar $1 \%$ maka permintaan telur itik akan naik sebesar $0,008 \%$, begitu juga sebaliknya. Tanda positif menunjukkan bahwa telur ayam ras merupakan barang subtitusi dari telur itik. Arti dari barang subtitusi merupakan barang pengganti, dengan kata lain kenaikan harga barang lain tersebut mengakibatkan kenaikan permintaan barang yang satunya lagi dan begitu pula sebaliknya (Suardi, 2019). Data di lapangan menyatakan bahwa dalam setiap bulan konsumen dapat membeli dua jenis telur untuk dikonsumsi yaitu teluritik dan telur ayam ras, hal tersebut menunjukkan bahwa dua jenis barang tersebut memiliki hubungan yang subtitutif.

Nilai elastisitas pendapatan keluarga sebesar 0,000007458. Artinya, jika terjadi kenaikan pendapatan sebesar $1 \%$ maka akan mengakibatkan bertambahnya jumlah permintaan telur itik 
sebesar 0,000007458\%, begitu juga sebaliknya. Angka elastisitas pendapatan yang bertanda positif menunjukkan bahwa telur itik merupakan barang normal. Harjanto \& Ariyani (2016) menyatakan bahwa besarnya nilai koefisien elastisitas pendapatan mempunyai makna tertentu yang menunjukkan sifat barang yang dihitung elastisitasnya yaitu barang normal (bertanda positif) dan barang inferior (bertanda negatif). Nilai elastisitas pendapatan tersebut bila dilihat persentasenya menunjukkan bahwa perubahan pendapatan hanya berpengaruh kecil terhadap permintaan telur itik.

\section{KESIMPULAN}

Variabel harga telur itik, harga telur ayam ras, pendapatan keluarga, jumlah anggota keluarga, jumlah kebutuhan, dan selera memiliki peran mempengaruhi permintaan telur itik di Kabupaten Jember secara serempak dan parsial; Variabel harga telur itik merupakan variabel yang paling dominan mempengaruhi permintaan telur itik di Kabupaten Jember; Permintaan telur itik bersifat inelastis, telur ayam ras merupakan barang subtitusi dengan telur itik, dan elastisitas pendapatan bernilai positif sehingga telur itik merupakan barang normal.

\section{DAFTAR PUSTAKA}

Bangun, W. (2017). Teori Ekonomi Mikro. Cetakan Kelima. Bandung: PT. Refika Aditama. Badan Pusat Statistik. (2019). Jember Dalam Angka 2019. Jember: Badan Pusat Statistik.

Dinas Peternakan Jawa Timur. (2018). Data Produksi Ternak Menurut Kabupaten/Kota. Retrieved Januari 07, 2020, from https://jatim.bps.go.id/statictable/2019/10/09/1611/produksi-telurunggas-dan-susu-sapi-menurut-kabupaten-kota-di-provinsi-jawa-timur-2017-2018.html

Fridayanti, N., Sri, M., \& Ernoiz, A. (2018). Analisis permintaan telur ayam di Kabupaten Magetan. Journal of Agricultural Socioeconomics and Bussiness, 01(02), 2621-3974. https://doi.org/10.22219/agriecobis.Vol1.No2.1-10

Harjanto, T., Ariyani, M. (2016). Ekonomi Mikro Analisis dan Pendekatan Praktis. Yogyakarta: Deepublish.

Hartono, B. (2016). Prinsip Analisis Ekonomi “Teori dan Aplikasi dibidang Peternakan”. Malang: UB Press.

Isman, F., Hamzah, A., \& Masbar. R. (2014). Analisis Permintaan Telur Ayam Ras di Provinsi Aceh. Jurnal Ilmu Ekonomi Pascasarjana Universitas Syiah Kuala, 02(02), 2302-0172. http://jurnal.unsyiah.ac.id/MIE/article/view/4676/4043

Murdani, B. (2018). Analisis Faktor-faktor yang Mempengaruhi Permintaan Konsumen terhadap Telur Ayam Ras di Desa Tambon Beroh Kecamatan Dewantara Kabupaten Aceh Utara. Jurnal AGRIFO, 03(01). https://doi.org/10.29103/ag.v3i1.674

Purnomo, R. (2016). Analisis Statistik Ekonomi dan Bisnis dengan SPSS. Ponorogo: CV. Wade Group.

Suardi, W. (2019). Modul Ekonomi Manajerial. Retrieved Januari 07, 2020, from https://www.researchgate.net/publication/330967763. 